\title{
Editorial
}

\section{Sandra Boto}

CIAC

Universidade do Algarve

Portugal

scboto@ualg.pt

\author{
Maria Guilhermina Castro \\ CITAR \\ Escola das Artes, Universidade Católica \\ Portuguesa \\ Portugal \\ mcastro@porto.ucp.pt
}

\author{
Ana Isabel Soares \\ CIAC \\ Universidade do Algarve \\ Portugal \\ asoares@ualg.pt
}

This issue of CITAR (Journal of Arts Science and Technology) is especially devoted to what we designated as Marginalized Narratives. It is a special issue that collects studies published upon the $5^{\text {th }}$ Colloquium on Narrative, Medium and Cognition, held at the University of Algarve in November 2018, and which was focused on that topic.

In line with what the colloquium proposed, the works now published share a broad understanding of the concept of narrative. The diversity of languages and media that the narratives in focus here explore present, however, as a common denominator, the fact that they bear indicators of marginality (or marginalization), in the diverse relations that can be established with the so-called erudite culture, canonical culture - anyhow with the culture that presents or perceives itself as hegemonic and central.

In "I Make Films to Be Seen": The Narrative Issue of Flora Gomes, Jusciele Conceição Almeida de Oliveira analyzes the cinematic narrative of Guinean director Flora Gomes. From this analysis, conclusions are drawn about the role played by several elements and categories (orality marks, the soundtrack, time and space, characteristics of the speech, filmic plans, among others), resulting from the thorough investigation carried out by the author, who, with this work, intends to claim the uniqueness of Flora Gomes' filmic works.

The analysis of the film narrative, in this case from a queer perspective, is also evident in the study "Queer Representation Incorporated in 'Him', a Character of 'The Powerpuff Girls', by Gustavo Rocha e Silva
Santos, Camila Peres Mancio and Elisa Maranho. It studies the representation of the character "Him" of the animation film Powerpuff Girls, considering its transsexual characteristics, while offering, on the other hand, a review of Brazil's queer cinema. The essay concludes that the early presentation of transgender characters with negative characteristics induces a transphobic view in children.

"Considerations About the Marginalized Narratives of Juliana Huxtable and DeForrest Brown Jr." is the proposal of João Ricardo Mateus, whose analysis focuses on the marginalized narratives from the analysis of two case studies: the works of Juliana Huxtable and those of DeForrest Brown Jr. It begins by contextualizing the multifaceted work of the two artists, and advances through a deepening analysis, pointing out convergences between the works of both, finally concluding by summarizing the foreshadowing contribution of a dialectical model of a plural social representation.

Narrativity and Audiovisual Performance, a study by Célia Vieira and Ana Carvalho, reflects on the impact that digital and, in particular, audiovisual artistic production, have on the concept of narrativity. The authors begin by elaborating a theoretical synthesis of the paths followed by narratology over the last decades (in both the structuralist and the poststructuralist paradigms). The core of the essay is the establishment of relationships between narrativity and audiovisual performance - an artistic practice that escapes the conventional mechanisms of narratological analysis -, namely through the study of specific cases with the objective of questioning 
principles considered fundamental in a traditional approach, pointing out the need for new conceptual tools, such as the association between narrativity and chance, improvisation, cyclicality, among other concepts that the authors pertinently bring to the discussion.

Following this sequence is an article that presents reflections on social inclusion, from the application of a film literacy project in Brazil: "Making Films in a Brazilian Slum with Children: a Participant Observation Research", by Raquel Pacheco and Mirna Juliana. The project is contextualized here from a theoretical point of view, and described in its practice, so that it provides a broad perspective of its application in a marginalized context, as well as the results obtained, which confirm the potential of cinema education as a promoter for the affirmation individuality and of cultural values.

"Nzinga Mbandi: From Story to Myth", by Orquídea Moreira Ribeiro, Fernando Alberto Torres Moreira and Susana Pimenta, focuses on literary narrative, particularly on the study of works produced around the mythical figure of the Angolan Queen Nzinga Mbandi (Ana de Sousa). The authors prove the importance of this figure in the construction of a nationalist imagination, which coincides with the appeal of resistance, when taken from the African perspective. The cases studied are the works of Manuel Pedro Pacavira, Nzinga Mbandi (1975), Pepetela'sThe Glorious Family: The Time of Flamingoes (1997), and José Eduardo Agualusa's Queen N'jinga and How Africans Invented the World (2014), whose readings now proposed by the authors highlight the ways in which the Angolan literary narrative absorbed and worked out a myth that eventually became a true symbol of postcolonialism.

The closing article is dedicated to the study of the boundaries between information and entertainment. "It's Online, It's News: Appropriation of Viral Narratives by the Digital Press" is signed by Ana Martins, Olivia Novoa Fernández, Ignacio Aguaded and Mirian Tavares, and it synthesizes the thinking of fundamental authors on the role of the nature of media in the discourse structure of knowledge, of truth; it then introduces concepts such as infotainment and politainment, referring to hybrid narratives which associate entertainment with information and politics, respectively, by further providing concrete examples of such products in digital media. The essay relates these hybrid genres (understood as narratives) to media such as television or video games. Newsgames are discussed here too, as well as viral marketing and satirical memes. The authors still discuss the spreading of digital news content, interactive infographics and viral messages on social networks. In the conclusion, the main functions of this digital news content are listed.

From literary and filmic narratives that address marginalized cultural realities to the narrative products of current digital communication, through to the approach of hybrid narratives that undermine prevailing narrative patterns, this special issue of CITAR proposes readings of phenomena which in one way or another challenge the center(s) and bring the margins to the spotlight. This fulfills the scientific willingness of the publishers for this special issue of the CITAR, through which we wish to contribute for a fruitful debate on the topic.

\section{BIOGRAPHICAL INFORMATION}

Sandra Boto has been an Assistant Researcher at the CIAC/University of Algarve (UAlg) since 2019. She has a degree in Modern Languages and Literature (Portuguese Studies) - from UAlg. In 2012 she earned her PhD in Languages, Literature and Cultures - Literary Studies from Universidade Nova de Lisboa, She is a member of CIAC (UAlg) and a collaborator of CLP (University of Coimbra). She is the scientific coordinator of the project Romanceiro.pt, endorsed by CIAC. She has lectured at UAlg, at the University of Huelva, and at the Universitat Autònoma de Barcelona, where she directed the Portuguese Language Center of Camões Institute. From her experience as a lecturer, we highlight teaching Portuguese for Foreigners and Spanish Literature.

Maria Guilhermina Castro is an Associate Professor at the School of Arts of the Catholic University of Portugal and has been working in other universities in different countries as Invited Professor. She investigates narrative and character creation at Research Centre for Science and Technology of Arts. She previously researched on other themes in the field of psychology of arts, as well as romantic relationships and career guidance (total of 10 projects), presenting these studies in over 60 scientific occasions including scientific journals, books, and conferences. Guilhermina co-organizes 
the Narrative, Media and Cognition Conference, which she co-founded. She was Vice-president of AIM - Association of Moving Image Researchers and she is co-responsible for the working group "Audiovisual Narratives" of this association. Guilhermina collaborated with CITAR Journal as assistant editor and she is reviewer of several academic journals. She received both her graduation and her doctorate in Psychology from the University of Porto (Portugal) and did advanced training in Morenian Psychodrama. It is worth mentioning her acting training through open courses at Superior School of Music and Performing Arts - Porto (ESMAE) and the advanced training in Psychotherapy and Career Guidance. Guilhermina was a psychologist in private practice and schools during eight years.

Ana Isabel Soares holds a PhD in Literary Theory (Lisbon University, 2003), and did a post-doctorate in the same program on Portuguese documentary films and poetry (2009-2010). She has taught graduation and post-graduation courses on English Literature and in Film Studies at Universidade do Algarve since 1996. A full member of CIAC - Centre for Research in Arts and Communication, she was one of the founders and the first President of AIM - Portuguese Association of Researchers of the Moving Image. Her publications range from literary to film studies. She has translated literary theory and poetry. 